\title{
THE SWORD OF AJAX: A REPORT ON DEMOCRACY AND SOLDIER SUICIDES
}

Might as well butcher the herd inside, fuck

it you said to the you inside, said it once and survived abandoning to it and then lived on saying it, then might as well fuck it fuck it fuck it like house-to-house fighting, no, the god said it to exonerate you inside the room after clearing the house, catch your breath then water before the shock of sunlight and crossing to the next house, they prize you like this the god, the monster nation-state jealous to keep you willing, wielding your possible death for the violence it can do, the power it secures, they dress it up "bulwark of the Achaeans" they call you or "America's finest young men and women," so what if after, the shock of sunglare leaving the movie house burns with your suddenly combat-pulse, so what if after, the little bells and metal jostle of the bodega's cash register becomes your anxious skin of sound like bronzeon-bronze melee, so what that your city's own gunfire heard a ways off, but close enough inside, so what if driving-fuck it-a hundred drunk miles an hour the freeway center lines might as well be the prized truce-sword of Ajax impaling another used-up soldier, so what if in the ditch of being something like drug-tired as the adrenalin metabolizes you say it to the exhausted suicide inside, exonerating- 
6256 veterans unequivocally killed themselves in 2005, and with only 45 states of the republic of near endless war reporting, the real total remains unknown. For the 20-24-year-old cohort, the soldiers experienced in the sand and cities, swelter and sieges of Iraq and Afghanistan, and damaged from those theaters' burning images, the suicide rate among these soldiers emeriti could reach 31.9 per 100,000, which would mean a suicide rate three times the civilian one. In 2009 (across the active-duty and reserve components), 239 soldiers suicided. In addition, 146 soldiers died from "high risk behavior," including 74 to drug overdose. In January alone (the month this poem began), 24 active-duty soldiers suicided. Almost exclusively they are men and mostly white, mostly they are soldiers or marines around the age of 23, mostly they shoot themselves out of theater (although a significant number suicide by hanging), and mostly each final cause remains unknown. And mostly they sought no counseling because of the stigma attached to "help-seeking behaviors." So no matter the complex of stressors, the stain of admitting psychic trauma cuts across all other risk factors. Almost to a man, the trauma equals a kind of shame that corrodes through humiliation-or annuls by death - a sense of being fully a man, for not being the "armsman" of the martial epic, the epic of state formation, of nation-building. The stigma is the negative reflection of an ideal where the soldier's "battlescarred body, like the city's ramparts, guards the tribe. [The soldier's body] is the body statufied, the human life reprieved from its brevity and magnified into architecture." The shell-shocked mind isn't the battle-scarred body and can't match its bare simplicity. And while General Casey may not have read Conrad's The Art of the City, he sure as fuck has felt the shadow of that ideal, even cultivated its presence as the esprit de corps to be felt-from balls to bones-by every soldier. At least now the suicide prevention video has interviews with soldiers (some who attempted suicide themselves) instead of low-rent actors in pristine uniforms playing at contemplating suicide. June 2010 saw 32 soldiers suicide, the worst month ever for this military body; these deaths are more than the combat deaths in Afghanistan over the same 
thirty days. In the first six months of 2010, already 145 soldiers have suicided, and at this rate soldier suicides will exceed the awful total of 2009. (Since this poem began, 384 soldiers have shot themselves or hanged or overdosed.) How many-impossible sum-General Chiarelli should ask, in his report on suicide prevention, how many since Virgil wrote down: arma virumque cano. Poetry is too durable; it must be defamed.

So the numbers: at least a reckoning.

So the numbers, looked at diachronically

like a core sample, looked at through

the overlapping discs of a Venn diagram,

the colliding halos of risk forming

the zone inside which the subject suicides

unequivocally. Looked at as a spike

in the graph. The doctors, because

they must, call it an epidemic.

So the numbers, so the cannot-be-

looked-through sunglare of this data set.

The blade and bullet are

worldless, so too the butchered

herd, sheep being poor in world

before Ajax (himself glorious

with it) butchered them inside, only they weren't rams, they were men- 
comrades of the same world,

war, and history-who the god

murdered expediently

through its bewildered proxy.

(So, detective, where does the god stand

in this ontology?

where your monster nation-state?)

52 